\title{
The effects of beetroot powder as a colorant on the color stability and product quality of white compound chocolate and chocolate spread
}

\author{
Abdullah BAYCAR ${ }^{1,2 *}$ (D), Nevzat KONAR 3 , Hamza GOKTAS² (iD, Osman SAGDIC ${ }^{2}$ (D), Derya Genç POLAT
}

\begin{abstract}
This study determines the possibility of using spread (SC) and compound chocolate (CC) as delivering agents of betalains, bioactive compounds and coloring agents. Therefore, the effects of various beetroot powder concentrations (0.0-1.00 g/100 g) on SC and CC's quality parameters and the associated visual properties over a 12-week period under accelerated shelf-life conditions were investigated. The hardness and plastic viscosity values of CC significantly increased as the amount of beetroot powder increased $(\mathrm{P}<0.05)$, the particle size while melting behavior, water activity, moisture content and sensory properties did not significantly change $(\mathrm{P}<0.05)$. The D90 and textural properties (firmness, stickiness, adhesion, work of shear) of the SC samples were significantly affected with the addition of beetroot powder $(\mathrm{P}<0.05)$, but no significant differences were observed in moisture content, water activity and some sensory properties $(\mathrm{P}>0.05)$. The use of beetroot powder for both groups caused a significant decrease in the samples' color values, and the redness associated with the pigment source also significantly increased $(\mathrm{p}<0.05)$. The findings revealed that high concentrations of beetroot powder did not significantly impact CC's color stability to the same extent that it impacted the SC's color stability. This study was made as a preliminary study to produce functional foods.
\end{abstract}

Keywords: confectionery; beetroot; chocolate spread; color stability; functional foods.

Practical Application: A bioactive feature has been added to the product, which lacks antioxidants. Contrary to most natural colorants, beetroot powder has shown a stable shelf-life. Functional food products with high sensory features were obtained.

\section{Introduction}

Due to increased awareness of relationships between health and nutrition, functional products have gained importance in recent years (Morato et al., 2015). Global chocolate providers currently supply a range of flavored and colored chocolate and chocolate products (e.g., compound chocolate, chocolate-coated wafers, chocolate chips, etc.). As milk and dark chocolate varieties are not suitable for coloring due to the cocoa powder they contain, white chocolate is suitable to be used for coloring products. White chocolate is used as a carrier for bioactive compounds that have also coloring effect. Even though these products are becoming more popular day by day, a limited amount of research has been performed in this area (Lončarević et al., 2018). As such, this study aimed to address gaps in understanding by investigating the impact of the use of natural colorants in chocolate technology both as pigment sources and coloring agents.

The natural colorant market's main components are carotenoids, anthocyanins, paprika extracts, curcumin, chlorophyll, and Spirulina. In addition to providing visual benefits, natural colorants can also offer a range of multi(functional) bioactive (e.g., antioxidant activity) and technological (e.g., preservative) impacts (Martins et al., 2016). Studies that have examined the multifunctional effects of different pigment sources in confectionery technology have also gained momentum, and the importance of "multi-effect observation" has been emphasized (Otálora et al., 2019).
Betalains are a plant-derived natural pigment that has gained increasing use in recent years as a natural colorant in the food industry (Gengatharan et al., 2015). Beetroot is the most widely used source of betalains (Georgiev et al., 2010). In addition to being a natural colorant, beetroot juice has been reported to reduce the cell mutations caused by the effect of nitrosamines, which are formed from nitrate (Delgado-Vargas et al., 2000). Moreover, thanks to its betalains and other bioactive components, beetroot juice and powder have the potential to prevent degenerative diseases such as blood pressure, cardiovascular diseases, and cancer (Gliszczyńska-Swigło et al., 2006; Clifford et al., 2015).

Beetroot powder, which is the source of betalains, has both coloring and bioactivity effects as a food ingredient. It is important to examine the effects of these and other colorantcontaining ingredients on the quality properties of foods before they are used for functional product development purposes, and also to ensure that the visual properties they provide are stable throughout their shelf life. The main aim of this study was to investigate usage possibilities and stability of beetroot powder as a source of betain in white chocolate spread (SC) and compound chocolate (CC) as coloring agent and to determine color stability during accelerated shelf conditions. Also, the effect of the use of beetroot powder on the main quality parameters as physical, physicochemical, thermo-gravimetric, rheological, textural and sensory properties of the samples were investigated by this study. 


\section{Materials and methods}

\subsection{Materials}

In the production of spread and compound chocolate samples, cocoa butter replacer (Trio30 and Unika44, AAK, Istanbul, Turkey), sugar powder (0.005-0.1 mm) (SMS Kopuz, Istanbul, Turkey), skimmed milk powder (Enka, Konya, Turkey), whey powder (Enka, Konya, Turkey), soy lecithin (Brenntag Chemistry, Istanbul, Turkey), sodium chloride (Salina, Konya, Turkey), polyglycerol polyriconalate (PGPR) (Palsgaard, Zierikzee, Netherlands), hazelnut flavor (Etol Frutarom, Kocaeli, Turkey), ethyl vanillin (Ekin Chemistry, Istanbul, Turkey), anhydrous vegetable fat (Orkide-41, Orkide, Izmir, Turkey), hazelnut puree (Segmen, Giresun, Turkey) and beetroot powder (Dohler, Karaman, Turkey) were used in this study.

\subsection{Methods}

Production of white compound chocolate and white chocolate spread

Total fat content has effects on many properties of chocolate products, e.g. texture, melting, flow behaviors and even color properties. However other components may also affect these properties, e.g. sugar, milk powder and emulsifiers. Therefore, to minimize component affect in this study, the formulation for all samples was arranged to be $100 \%$ complete by beetroot powder. For the production of compound chocolate (Figure 1); sugar powder $\left(450.0 \mathrm{~g} \mathrm{~kg}^{-1}\right)$, cocoa butter replacer $\left(200.0 \mathrm{~g} \mathrm{~kg}^{-1}\right)$, whey powder $\left(112.8 \mathrm{~g} \mathrm{~kg}^{-1}\right)$, skimmed milk powder $\left(130.0 \mathrm{~g} \mathrm{~kg}^{-1}\right)$, soy lecithin $\left(1.67 \mathrm{~g} \mathrm{~kg}^{-1}\right)$ were homogenized in the mixer, and subsequently were refined in a 3-roll refiner (Lehmann, Aalen, Germany) to $20 \mu \mathrm{m}$.

The refined mass was added to the cocoa butter replacer (100.0 $\left.\mathrm{g} \mathrm{kg}^{-1}\right)$, soy lecithin $\left(1.83 \mathrm{~g} \mathrm{~kg}^{-1}\right)$, PGPR $\left(2.00 \mathrm{~g} \mathrm{~kg}^{-1}\right)$, hazelnut flavor $\left(1.50 \mathrm{~g} \mathrm{~kg}^{-1}\right)$, vanillin $\left(0.20 \mathrm{~g} \mathrm{~kg}^{-1}\right)$. All these components were conched for 6 hours at $60^{\circ} \mathrm{C}$ by using a laboratory conche (BSA Scheinder, Angalentechnik, Aachen, Germany). Samples $\mathrm{C} 00, \mathrm{C} 025, \mathrm{C} 050, \mathrm{C} 075$ and C100 were prepared by using the components as $1000 \mathrm{~g} \mathrm{~kg}^{-1}, 997.5 \mathrm{~g} \mathrm{kg-}^{1}, 995.0 \mathrm{~g} \mathrm{~kg}^{-1}, 992.5 \mathrm{~g} \mathrm{~kg}^{-1}$, $990.0 \mathrm{~g} \mathrm{~kg}^{-1}$, respectively and then mixed with beetroot powder $\left(0.00 \mathrm{~g} \mathrm{~kg}^{-1}, 2.50 \mathrm{~g} \mathrm{~kg}^{-1}, 5.00 \mathrm{~g} \mathrm{~kg}^{-1}, 7.50 \mathrm{~g} \mathrm{~kg}^{-1}, 10.0 \mathrm{~g} \mathrm{~kg}^{-1}\right)$ for 5 minutes and subsequently molded (diameter: $35.8 \mathrm{~mm}$, depth: $7.3 \mathrm{~mm}$ ). After $20 \mathrm{~min}$ of cooling (Aasted Farum, Denmark) at $5{ }^{\circ} \mathrm{C}$, the process was completed. The samples removed from the cooling tunnel (Aasted, Farum, Denmark) were wrapped in aluminum foil and packed. Samples were stored at temperatures between 15 and $18^{\circ} \mathrm{C}$, and subsequently prevented from light and heat prior to analysis.

For the production of spread chocolate samples; sugar powder (450.0 $\left.\mathrm{g} \mathrm{kg}^{-1}\right)$, anhydrous vegetable fat $\left(260.0 \mathrm{~g} \mathrm{~kg}^{-1}\right)$, whey powder $\left(135.8 \mathrm{~g} \mathrm{~kg}^{-1}\right)$, skimmed milk powder $\left(120 \mathrm{~g} \mathrm{~kg}^{-1}\right)$, soy lecithin $\left(2.50 \mathrm{~g} \mathrm{~kg}^{-1}\right)$, hazelnut puree $\left(30.0 \mathrm{~g} \mathrm{~kg}^{-1}\right)$, hazelnut flavor $\left(1.50 \mathrm{~g} \mathrm{~kg}^{-1}\right)$, vanillin $\left(0.20 \mathrm{~g} \mathrm{~kg}^{-1}\right)$ were used. The spread samples were prepared by using a pilot-scale ball-mill (Alpy, Istanbul, Turkey). Refining-conching time and shaft speeds were 45 minutes and $60 \mathrm{rpm}$, respectively, at $45^{\circ} \mathrm{C}$. Samples of S00, S025, S050, S075 and S100 were prepared from the components of $1000 \mathrm{~g} \mathrm{~kg}^{-1}, 997.5 \mathrm{~g} \mathrm{~kg}^{-1}, 995.0 \mathrm{~g} \mathrm{~kg}^{-1}, 992.5 \mathrm{~g} \mathrm{~kg}^{-1}, 990.0 \mathrm{~g} \mathrm{~kg}^{-1}$ and then each of those components were mixed with beetroot powder of $0.00 \mathrm{~g} \mathrm{~kg}^{-1}, 2.50 \mathrm{~g} \mathrm{~kg}^{-1}, 5.00 \mathrm{~g} \mathrm{~kg}^{-1}, 7.50 \mathrm{~g} \mathrm{~kg}^{-1}, 10.0 \mathrm{~g} \mathrm{~kg}^{-1}$, respectively which were mixed for 5 minutes. Samples were cooled after deposited in $60 \mathrm{~mL}$ cups at $12{ }^{\circ} \mathrm{C}$.

\section{Physicochemical analysis}

The water activities of the spread and compound chocolates were measured using a Lab-Master $\mathrm{a}_{\mathrm{w}}$ (Novasina, Switzerland) according to the method used by Konar (2013). $a_{w}$ value of each sample was measured in triplicate after a follow-up day of sample preparation. Determination of the moisture content of spread and compound chocolate samples and ingredients were
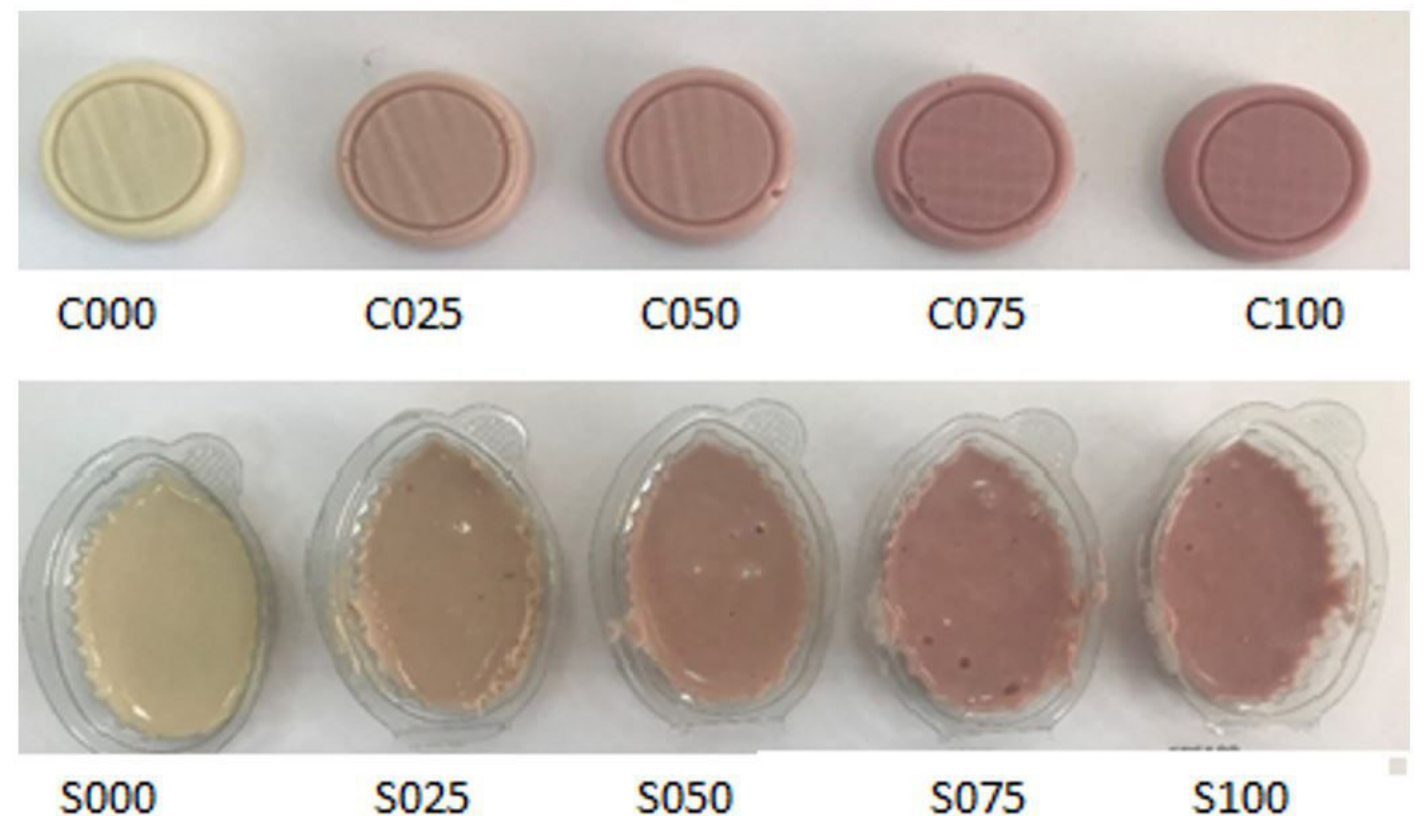

Figure 1. The colored white compound chocolate and chocolate spread samples. 
performed using the method previously reported by Lonchampt \& Hartel (2006).

\section{Particle size}

The particle sizes of the produced spread and compound chocolate samples and ingredients were determined by using micrometers (Mitutoyo, Manufacturing Co. Ltd., Japan, $0.001 \mathrm{~mm}$ accuracy) (Toker et al., 2017).

\section{Color and color stability analysis}

Color parameters of spread and compound chocolate samples $\mathrm{L}^{*}$ : brightness, $\mathrm{a}^{*}: \pm$ red; -green, and $\mathrm{b}^{*}: \pm$ yellow; -blue were determined using colorimeters (Chroma Meter CR-400, Konica Minolta, Japan) in the SCI-mode (Specular Component Included). The colorimeter was designed in diffusion illumination $0^{\circ}$ viewing angle geometry. Chroma $\left(\mathrm{C}^{\star}\right)$, hue $\left(\mathrm{h}^{\circ}\right)$, whiteness index $\left(\mathrm{WI}^{\star}\right)$ values were calculated using the Equations 1, 2 and 3 in the CIELAB system. Spread and compound chocolate samples were stored the day after production at accelerated shelf-life conditions $\left(25^{\circ} \mathrm{C}\right.$ and $\left.70 \% \mathrm{RH}\right)$ (Subramaniam, 2007). For 7 -day periods for 12 weeks, $\mathrm{L}^{*}, \mathrm{a}^{*}$ and $\mathrm{b}^{*}$ values of samples were measured color stability $(\Delta \mathrm{E})$ values were calculated by using Equation 4 (Periche et al., 2015);

$$
\begin{aligned}
& C^{*}=\sqrt{a^{*^{2}+b^{* 2}}} \\
& h^{\circ}=\arctan \left(b^{*} / a^{*}\right) \\
& W I=100-\left[(100-L)^{2}+a^{2}+b^{2}\right]^{1 / 2} \\
& \ddot{A} E=\left[\left(\ddot{A} L^{*}\right)^{2}+\left(\ddot{A} a^{*}\right)^{2}+\left(\ddot{A} b^{*}\right)^{2}\right]^{1 / 2}
\end{aligned}
$$

\section{Sensory analysis}

Five-point hedonic scale sensory analyses were conducted to identify significant differences between samples. The sensory evaluation test was carried out by panelists. The panel $(n=30)$ was composed of staff and graduate students from the Department of Food Engineering at Siirt University. The age composition of the panelists was $76.6 \%(18-25)$ and $23.4 \%(30-46)$ and the gender composition was $43.3 \%$ male and $57.7 \%$ female. Panelists evaluated the effects of using beetroot powder in various concentrations on the sensory characteristics of spread and compound chocolate samples, as appearance, brightness, color, melting in mouth, sweetness, flavor, taste, intense buying and general acceptance. Between each assessment, panelists were given a cup of water and crackers to consume.

\section{Texture analysis}

As a textural parameter, hardness values of the compound chocolate samples were determined using TA-TX plus Texture Analyser (Stable Micro systems, Surrey, UK). During analyses, load cell with $5 \mathrm{~kg}$ and 3-point bend ring were used to obtain displacement versus force curve. By using this curve force at peak, necessary for breaking the sample, was calculated. The trigger force was set to $0.05 \mathrm{~N}$. Pre-test, test and post-test speeds applied during textural measurement were $1 \mathrm{~mm} / \mathrm{sec}, 1 \mathrm{~mm} / \mathrm{sec}$ and $10 \mathrm{~mm} / \mathrm{sec}$, respectively. Hardness values $(\mathrm{N})$ were expressed as the mean value of 5 replicates (Konar, 2013). In the texture analysis of spread samples, the firmness, stickiness, adhesion and work of shear parameters of the samples were determined by using a modified method, which was described previously by McGill \& Hartel (2018). According to the analysis, texture parameters of samples were determined by a conical $90^{\circ}$ angle probe and texture analyser (TA.HD Plus, Stable Micro System, Godalming, UK) based on shear stress under controlled temperature with a compression force of $55 \mathrm{~mm}$ distance and a speed of $3 \mathrm{~mm} / \mathrm{s}$.

\section{Melting behavior}

Melting behavior of the compound chocolate samples was determined using DSC (TA Q20, USA) according to the method reported by Glicerina et al. (2013). Samples ( $5 \mathrm{mg}$ ) were put into pans with a hermetic lid. The samples were heated from 0.00 to $60.0^{\circ} \mathrm{C}$ at $10.0^{\circ} \mathrm{C} / \mathrm{min}$ in $\mathrm{N}_{2}$ stream. Onset temperature (Tonset, beginning of the melting), peak temperature (Tpeak), end temperature (Tend, complete melting) and energy required for the complete melting of the samples $(\Delta \mathrm{H}$, amount of energy necessary for complete melting) were calculated using thermograms obtained.

\section{Flow behavior}

Flow behavior of the melted compound chocolate samples was determined at $40{ }^{\circ} \mathrm{C}$ using strain-controlled rheometer (Anton Paar, MCR 302, Austria). Cylindrical probe system was used for the determination of rheological parameters (Toker et al., 2016). Upward and downward shear rate ranged from 0.10 to $50.0 \mathrm{~s}^{-1}$ and from $50.0 \mathrm{~s}^{-1}$ to $0.10 \mathrm{~s}^{-1}$ were applied. For each curve (upward and downward), corresponding parameters of the Casson model were calculated using the following Equation 5:

$\tau^{0.5}=\tau_{0}^{0.5}+\eta_{p l} \gamma^{n}$

where $\tau$ is shear stress $(\mathrm{Pa}), \gamma$ is shear rate $\left(\mathrm{s}^{-1}\right), \tau_{0}$ is the yield stress $(\mathrm{Pa})$ and $\eta_{p l}$ is plastic viscosity $(\mathrm{Pa} \mathrm{s})$.

\section{Statistical analysis}

The measured data were expressed as the mean \pm standard deviation. The results were analyzed with analysis of variance (ANOVA). Tukey's test was applied to determine if the effect of beetroot powder on the related parameters of spread and compound chocolates was significant or not at a confidence level of 0.05 . The statistical analyses were conducted using the MINITAB 16.0 (Minitab Inc., State College, PA, USA).

\section{Results and discussion}

\subsection{Physicochemical properties}

The moisture content is of critical significance for chocolate products as a relationship exists between the amount of moisture and shelf-life of the products and its other main quality parameters such as hardness, viscosity and melting. The moisture value of 
these products is expected to be $<1.50 \mathrm{~g} / 100 \mathrm{~g}$. This value is determined by process conditions (Konar \& Bingol, 2019) and product composition (Afoakwa, 2010). In this study, the moisture values of compound chocolate samples were in the range of 0.77-1.44 g/100 g, which corresponds to the values below the critical level (Table 1). Even though the use of beetroot powder at different levels caused an increase in the moisture content, this increase was not significant $(\mathrm{P}>0.05)$. Moisture content of spread samples were determined at the range of 1.46-2.00 g/100 g (Table 1). Spread samples, similar to compound chocolate, also showed an increase in moisture content when beetroot was used in general. This increase, however, was not significant $(\mathrm{P}>0.05)$. Betaine is a highly polar compound and has a hydrophilic character (Rivoira et al., 2017). The reason for increased moisture content in samples which contain beetroot might be these features of betalains. However, at the stage where this pigment source is added to the sample mass in the process, it is likely that the process of water removal from the structure has been completed (Konar \& Bingol, 2019). Therefore, it can be stated that the change in moisture level is a possible result of the affinity of betalains to moisture due to the environmental conditions.

The water activity values of compound chocolate and spread samples showed a narrow change, $0.24-0.25$ and $0.30-0.34$, respectively (Table 1 ). The use of beetroot powder did not cause significant change for this parameter $(\mathrm{P}>0.05)$. Chocolate and its derivative products are generally described as a food with low water activity (Nascimento et al., 2012). The water activity of chocolate was generally between $0.4-0.5$, but factors such as the raw materials used, the surface area of the materials and particle size, the duration and temperature of the conching may affect the water activity value. Considering the storage period, the target value for water activity can be specified as $<0.40$ (Konar, 2013).

The $\mathrm{D}_{90}$ value obtained from the particle size distribution (a value that is less than $90 \%$ of the particle size) is consistent with the value measured by the micrometer (Beckett, 2009). Particle size values above $35 \mu \mathrm{m}$ cause sandy-sense in the mouth (Schumacher et al., 2009). It is already known that small particles improve the sensory properties of chocolate (Ziegler et al., 2001). In this study, $\mathrm{D}_{90}$ values of compound chocolate were determined to be between 30.3 - $33.3 \mu \mathrm{m}$ (Table 2). The use of beetroot powder did not have a significant effect on this parameter. However, $D_{90}$ values of spread samples increased significantly with the use of this betalains source $(\mathrm{P}<0.05)$. Possible causes of this rise include increased amount of moisture and thus causing agglomeration. However, with the modification of the ball-mill process (time, temperature and $\mathrm{rpm}$ ), it may be possible to refine the samples containing beetroot powder to have an aimed particle size.

\subsection{Textural properties}

Textural properties are among the major quality parameters for chocolate and derivative products (Beckett, 2009; Afoakwa, 2010). One of the main textural quality parameters in chocolate is hardness. The hardness of the chocolate samples is indicated by the type and amount of fat used, the type of sugar, the particle size distribution, tempering conditions as well as the temperature of the conching (Afoakwa et al., 2008; Shourideh et al., 2012; Tan \& Balasubramanian, 2017). In this study, the hardness properties of the compound chocolate samples were investigated. The hardness of the compound samples varied in the range of 4413-7893 $\mathrm{g}$ (Table 1). The addition of beetroot powder caused a significant increase in hardness $(\mathrm{p}<0.05)$. However, the increase was not associated with the level of pigment source. Chocolate quality is associated with its textural hardness feature and "snap," which is one of its results. In order to consider a chocolate as a high-quality chocolate, a certain level of hardness is expected (Konar, 2013). Therefore, the obtained result can be considered to be positive. However, it is noteworthy to mention that increase in moisture (though in insignificant amount) and hardness occurred together in the samples.

Firmness, stickiness, adhesion and work of shear properties of spread samples were also determined. The results of these properties were found to be varied between 414-663 g, (-410) - (-611) g/min, and $349-585 \mathrm{~g} / \mathrm{min}$, respectively. Although there were significant differences between the sample groups $(\mathrm{P}<0.05)$, a relationship between this difference and the amount of beetroot powder used could not be identified. A reduction in the amount of beetroot used based on the ratios in the control sample composition from all components may be one of the reasons for the obtained results. Some components affect the spread textural properties in various impact and directions. Major components such as fat phase composition and concentration (Manzocco et al., 2014;

Table 1. Physicochemical and textural properties of colored white compound chocolate and chocolate spread.

\begin{tabular}{|c|c|c|c|c|c|c|c|}
\hline \multirow[b]{2}{*}{ Sample } & \multicolumn{2}{|c|}{ Physicochemical } & \multicolumn{5}{|c|}{ Texture } \\
\hline & Water activity & $\begin{array}{l}\text { Moisture } \\
(\mathrm{g} / 100 \mathrm{~g})\end{array}$ & Firmness (g) & Stickiness (g) & Adhesion (g/min) & $\begin{array}{c}\text { Work of Shear } \\
\text { (g.min) }\end{array}$ & Hardness (g) \\
\hline $\mathrm{C} 000$ & $0.25 \pm 0.029^{a}$ & $0.77 \pm 0.23^{\mathrm{a}}$ & nd & nd & nd & nd & $4413 \pm 313^{c}$ \\
\hline C025 & $0.25 \pm 0.01^{\mathrm{a}}$ & $1.06 \pm 0.48^{\mathrm{a}}$ & nd & nd & nd & nd & $7893 \pm 171^{\mathrm{a}}$ \\
\hline $\mathrm{C} 050$ & $0.25 \pm 0.02^{\mathrm{a}}$ & $1.07 \pm 0.29^{\mathrm{a}}$ & nd & nd & nd & nd & $6633 \pm 265^{b}$ \\
\hline C075 & $0.24 \pm 0.01^{\mathrm{a}}$ & $1.14 \pm 0.29^{\mathrm{a}}$ & nd & nd & nd & nd & $6777 \pm 135^{\mathrm{b}}$ \\
\hline C100 & $0.25 \pm 0.02^{\mathrm{a}}$ & $1.44 \pm 0.35^{\mathrm{a}}$ & nd & nd & nd & nd & $6393 \pm 47^{\mathrm{b}}$ \\
\hline S000 & $0.34 \pm 0.02^{\mathrm{a}}$ & $1.46 \pm 0.28^{\mathrm{a}}$ & $588 \pm 87^{\mathrm{ab}}$ & $-611 \pm 76.7^{b}$ & $-268 \pm 30.7^{b c}$ & $480.4 \pm 61.0^{\mathrm{ab}}$ & nd \\
\hline S025 & $0.30 \pm 0.01^{\mathrm{a}}$ & $1.80 \pm 0.14^{\mathrm{a}}$ & $414 \pm 2.20^{\mathrm{b}}$ & $-410 \pm 2.70^{\mathrm{a}}$ & $-182 \pm 1.20^{\mathrm{a}}$ & $349.1 \pm 14.5^{\mathrm{b}}$ & nd \\
\hline S050 & $0.31 \pm 0.01^{\mathrm{a}}$ & $2.00 \pm 0.33^{\mathrm{a}}$ & $663 \pm 26.4^{\mathrm{a}}$ & $-652 \pm 39.7^{b}$ & $-329 \pm 13.1^{c}$ & $585.6 \pm 15.3^{\mathrm{a}}$ & nd \\
\hline S075 & $0.30 \pm 0.01^{\mathrm{a}}$ & $1.40 \pm 0.53^{\mathrm{a}}$ & $648 \pm 61.6^{\mathrm{a}}$ & $-588 \pm 52.7^{\mathrm{ab}}$ & $-252 \pm 22.5^{\mathrm{abc}}$ & $575.6 \pm 73.4^{\mathrm{a}}$ & nd \\
\hline $\mathrm{S} 100$ & $0.30 \pm 0.01^{\mathrm{a}}$ & $1.80 \pm 0.28^{\mathrm{a}}$ & $516 \pm 18.3^{\mathrm{ab}}$ & $-525 \pm 2.60^{\mathrm{ab}}$ & $-246 \pm 22.1^{\mathrm{ab}}$ & $416.4 \pm 30.2^{\mathrm{ab}}$ & nd \\
\hline
\end{tabular}

nd: Not determined. Different superscript lowercase letters show the significant differences for each sample $(P<0.05)$. All experiments were performed in triplicate. All data are represented as means \pm standard deviation. 
Table 2. Particle size $\left(\mathrm{D}_{90}\right)$ and color properties of colored white compound chocolate and chocolate spread.

\begin{tabular}{|c|c|c|c|c|c|c|c|}
\hline \multirow{2}{*}{ Sample } & \multirow{2}{*}{$\mathrm{D}_{90}(\mu \mathrm{m})$} & \multicolumn{6}{|c|}{ CIE-Lab } \\
\hline & & $\mathrm{L}^{*}$ & $a^{*}$ & $b^{*}$ & $\mathrm{C}^{\star}$ & $\mathrm{h}^{\circ}$ & WI \\
\hline $\mathrm{C} 000$ & $30.3 \pm 0.58^{a}$ & $74.4 \pm 0.6^{\mathrm{a}}$ & $-5.90 \pm 0.10^{\mathrm{d}}$ & $18.2 \pm 0.15^{\mathrm{a}}$ & $19.2 \pm 0.15^{\mathrm{a}}$ & $-72.0 \pm 0.12^{\mathrm{e}}$ & $68.0 \pm 0.42^{\mathrm{a}}$ \\
\hline $\mathrm{C} 025$ & $33.3 \pm 1.53^{\mathrm{a}}$ & $65.9 \pm 0.1^{\mathrm{b}}$ & $3.90 \pm 0.20^{c}$ & $12.4 \pm 0.60^{\mathrm{b}}$ & $13.0 \pm 0.63^{b}$ & $72.6 \pm 0.38^{\mathrm{a}}$ & $63.5 \pm 0.28^{\mathrm{b}}$ \\
\hline $\mathrm{C} 050$ & $33.0 \pm 1.73^{\mathrm{a}}$ & $65.3 \pm 0.5^{\mathrm{b}}$ & $4.20 \pm 0.00^{\mathrm{b}}$ & $12.6 \pm 0.18^{\mathrm{b}}$ & $13.3 \pm 0.19^{c}$ & $71.5 \pm 0.20^{\mathrm{b}}$ & $62.9 \pm 0.41^{\mathrm{b}}$ \\
\hline $\mathrm{C} 075$ & $31.7 \pm 1.15^{\mathrm{a}}$ & $57.2 \pm 0.2^{\mathrm{c}}$ & $10.77 \pm 0.20^{\mathrm{b}}$ & $9.2 \pm 0.05^{c}$ & $14.2 \pm 0.16^{\mathrm{d}}$ & $40.7 \pm 0.54^{c}$ & $54.9 \pm 0.20^{c}$ \\
\hline $\mathrm{C} 100$ & $33.3 \pm 1.53^{\mathrm{a}}$ & $54.9 \pm 0.7^{\mathrm{d}}$ & $12.8 \pm 0.10^{\mathrm{a}}$ & $8.2 \pm 0.10^{\mathrm{d}}$ & $15.3 \pm 0.13^{\mathrm{d}}$ & $32.7 \pm 0.16^{\mathrm{d}}$ & $52.4 \pm 0.61^{\mathrm{d}}$ \\
\hline S000 & $19.0 \pm 0.85^{c}$ & $68.4 \pm 0.16^{\mathrm{a}}$ & $-2.61 \pm 0.11^{\mathrm{e}}$ & $17.3 \pm 0.06^{\mathrm{a}}$ & $17.5 \pm 0.08^{\mathrm{a}}$ & $-81.4 \pm 0.32^{\mathrm{e}}$ & $63.9 \pm 0.12^{\mathrm{a}}$ \\
\hline S025 & $25.0 \pm 1.00^{\mathrm{b}}$ & $63.5 \pm 0.35^{\mathrm{b}}$ & $2.47 \pm 0.33^{\mathrm{d}}$ & $14.3 \pm 0.07^{\mathrm{b}}$ & $14.5 \pm 0.01^{\mathrm{b}}$ & $80.2 \pm 1.34^{\mathrm{a}}$ & $60.7 \pm 0.32^{\mathrm{b}}$ \\
\hline S050 & $31.7 \pm 0.58^{\mathrm{a}}$ & $60.1 \pm 0.33^{c}$ & $5.61 \pm 0.41^{c}$ & $12.1 \pm 0.37^{c}$ & $13.3 \pm 0.32^{c}$ & $65.1 \pm 1.94^{\mathrm{b}}$ & $57.9 \pm 0.37^{c}$ \\
\hline S075 & $30.7 \pm 0.58^{a}$ & $56.6 \pm 0.38^{\mathrm{d}}$ & $8.95 \pm 0.24^{\mathrm{b}}$ & $10.9 \pm 0.13^{\mathrm{d}}$ & $14.1 \pm 0.08^{c}$ & $50.7 \pm 1.07^{c}$ & $54.3 \pm 0.38^{\mathrm{d}}$ \\
\hline S100 & $31.3 \pm 2.08^{\mathrm{a}}$ & $54.2 \pm 0.58^{\mathrm{e}}$ & $10.78 \pm 0.37^{\mathrm{a}}$ & $10.0 \pm 0.15^{\mathrm{e}}$ & $14.7 \pm 0.18^{\mathrm{d}}$ & $42.9 \pm 1.39^{\mathrm{d}}$ & $51.9 \pm 0.60^{\mathrm{e}}$ \\
\hline
\end{tabular}

Different superscript lowercase letters show the significant differences for each sample group $(P<0.05)$. All experiments were performed in triplicate. All data are represented as means \pm standard deviation.

Fayaz et al., 2017) and milk powder level and composition (Sethi \& Balasubramanyam, 2018), as well as minor components such as lecithin, have an effect on textural properties of spread. Therefore, it may be useful to study the effects of components for textural properties of spread formulation prepared using pigment sources in future studies.

\subsection{Sensory properties}

Appearance, aroma, flavor and texture can be specified as the main sensory characteristics for the spread chocolate. The color should also be taken into consideration in spreadable products to meet the consumer acceptance. Therefore, in our study, parameters such as appearance, melting in mouth, sweetness, flavor, taste, buying intense and general acceptance, as well as brightness and color parameters were examined for both compound chocolate and spread samples within the scope of sensory analysis. In the study, a five-point hedonic scale was used, panelists scored these parameters for compound chocolate samples, 4.40-4.80, 4.37-4.93, 4.60-4.80, 4.70-4.80, 4.67-4.77, $4.63-4.73,4.63-4.77,4.57-4.70$ and $4.33-4.77$, respectively. The results of spread samples determined as 4.27-4.83, 4.17-4.77, $4.27-4.70,4.13-4.67,4.50,4.70,4.13-4.53,4.37-4.67,4.304 .53$ and 4.57-4.80, respectively (Table 3 ). As all panelists' evaluations were $>4.0$ scores, both for compound and spread chocolate, the result can be considered to be positive.

No significant change was determined in using beetroot powder (along with its use in different levels), when it was compared to the control sample, in the sensory properties of brightness, sweetness, flavor, taste, buying intense and general acceptance in compound chocolate samples $(\mathrm{P}>0.05)$. For spread samples, however, this was the case only for brightness, sweetness, taste, buying intense and general acceptance $(P>0.05)$. One of the main objectives of this study is to investigate the possibility of coloring the samples with beetroot powder. It is because of this aim that the level of color appreciation is of particular importance. The highest color liking in the compound samples was acquired for the control sample and the sample containing $1.00 \mathrm{~g} / 100 \mathrm{~g}$ beetroot powder $(\mathrm{P}<0.05)$. In spread samples, however, the highest rating of all, including control sample, was given to the sample which was prepared by using $1.00 \mathrm{~g} / 100 \mathrm{~g}$ beetroot powder $(\mathrm{P}<0.05)$. Similarly, the highest values for both compound and spread chocolate's appearance likings were determined for the samples used in the mentioned proportion of pigment sources $(\mathrm{P}<0.05)$. This result can be considered as an advantage for the use of compound and spread chocolate as a means of distribution of bioactive compounds. As there was an increase in the level of appreciation of the samples which were prepared with the use of these components at high levels. However, further studies need to examine the concentrations of related bioactive compounds as well as their interactions with other components in the matrix for bioaccessibility and bioactivity. Significant decrease in flavor liking was determined after using a coloring agent in spread samples $(\mathrm{p}<0.05)$. Consumers can establish a relationship between aroma and color in confectionery products (Saint-Eve et al., 2011). The reason for the decrease in flavor liking level in spread samples may be that the color of the samples was not associated with its aroma by panelists.

\subsection{Flow and melting behaviors}

In this study, flow (yield stress and plastic viscosity) and melting $\left(\mathrm{T}_{\text {onset }}, \mathrm{T}_{\text {peak }}, \mathrm{T}_{\text {end }}\right.$ and $\left.\Delta \mathrm{h}\right)$ behaviors of compound chocolate samples with different levels of beetroot powder were determined (Table 4). The rheological properties of chocolate have a significant effect on the quality and stability of the end product due to its effect on parameters such as viscosity, consistency and mouth sensation (Glicerina \& Romani, 2016). The yield stress and plastic viscosity values of the samples were determined between 1.68-2.02 $\mathrm{Pa}$ and 2.09-2.50 Pa.s, respectively. Even though the values of both properties increased with the use of beetroot powder, no significant change was determined $(P>0.05)$. Chocolate flow properties are affected not only by the process conditions (refining, conching and tempering) but also by the composition (Vavreck, 2004; Schantz \& Rohm, 2005). In this study, one of the main reasons for the increase in yield stress and plastic viscosity values may be the higher moisture values in compound chocolate samples compared to the control sample. Servais et al. (2003) underlined that any fluctuation or change in the moisture level of chocolate can cause significant changes in the viscosity value of the sample. At moisture levels below $1.0 \%$, most of the water is bonded and its effect on flow characteristics is negligible. Thickening begins, however, when the chocolate begins to absorb moisture (Wolf, 2017). 
Table 3. Sensory properties of colored white compound chocolate and chocolate spread.

\begin{tabular}{|c|c|c|c|c|c|c|c|c|c|}
\hline le & ppearance & rightness & Color & $\begin{array}{c}\text { Melting in } \\
\text { mouth }\end{array}$ & Swe & Flavor & Taste & $\begin{array}{l}\text { Buying } \\
\text { intense }\end{array}$ & $\begin{array}{c}\text { General } \\
\text { Acceptance }\end{array}$ \\
\hline $\mathrm{C} 000$ & & & 73 & $4.93 \pm 0.25^{\mathrm{a}}$ & 80 & $80 \pm 0.42^{\mathrm{a}}$ & $4.77 \pm 0$ & $4.63 \pm 0.49^{\mathrm{a}}$ & $4.73 \pm 0.49^{\mathrm{a}}$ \\
\hline $\mathrm{C} 025$ & $40 \pm 0.72^{\mathrm{ab}}$ & $4.57 \pm 0.50^{\mathrm{a}}$ & $4.33 \pm 0.66^{\mathrm{b}}$ & $90 \pm 0.31^{\mathrm{a}}$ & $4.80 \pm 0.48^{\mathrm{a}}$ & $4.70 \pm 0.47^{\mathrm{a}}$ & $4.77 \pm 0.43^{\mathrm{a}}$ & $4.63 \pm 0.56^{\mathrm{a}}$ & $4.70 \pm 0.46^{\mathrm{a}}$ \\
\hline C050 & $53 \pm 0.63^{\mathrm{ab}}$ & $4.63 \pm 0.49^{\mathrm{a}}$ & $4.47 \pm 0.57^{\mathrm{ab}}$ & $80 \pm 0.41^{\mathrm{a}}$ & $4.80 \pm 0.48^{\mathrm{a}}$ & $4.70 \pm 0.47^{\mathrm{a}}$ & $4.77 \pm 0.43^{\mathrm{a}}$ & $4.63 \pm 0.56^{\mathrm{a}}$ & $4.70 \pm 0.46^{\mathrm{a}}$ \\
\hline C075 & $1.67 \pm 0.48^{\mathrm{ab}}$ & $5 \pm 0.48^{\mathrm{a}}$ & $4.60 \pm 0.50^{\mathrm{ab}}$ & $4.63 \pm 0.56^{\mathrm{ab}}$ & $4.60 \pm 0.56^{\mathrm{a}}$ & $1.70 \pm 0.47^{\mathrm{a}}$ & $.67 \pm 0.48^{a}$ & $.63 \pm 0.49^{a}$ & $4.63 \pm 0.49^{\mathrm{a}}$ \\
\hline $\mathrm{C} 1$ & & & & & & & & & \\
\hline S000 & $2^{\mathrm{b}}$ & $4.53 \pm$ & $4.57 \pm 0.5683^{\mathrm{ab}}$ & $4.77 \pm 0$ & $4.70=$ & $4.67=$ & $4.63 \pm$ & $4.47 \pm$ & 4.57 \\
\hline S025 & $4^{\mathrm{ab}}$ & $413+$ & $4.37 \pm 0.56^{\mathrm{b}}$ & $4.53 \pm 0.68^{\mathrm{ab}}$ & $4.47 \pm$ & $4.33 \pm 0.55^{\mathrm{ab}}$ & $4.50 \pm 0.63^{\mathrm{a}}$ & $4.13 \pm 0.78^{\mathrm{a}}$ & $4.37 \pm 0.56^{\mathrm{a}}$ \\
\hline S050 & $4.50 \pm 0.57^{\mathrm{ab}}$ & $4.33 \pm 0.66^{\mathrm{a}}$ & $4.47 \pm 0.57^{\mathrm{ab}}$ & $4.47 \pm 0.57^{\mathrm{ab}}$ & $4.43 \pm 0.73^{\mathrm{a}}$ & $4.30 \pm 0.75^{\mathrm{ab}}$ & $4.63 \pm$ & $4.13 \pm 0.73^{\mathrm{a}}$ & $4.47 \pm 0.51^{\mathrm{a}}$ \\
\hline S075 & & $4.30 \pm 0.65^{\mathrm{a}}$ & $4.67 \pm 0.48^{\mathrm{ab}}$ & & $4.43 \pm 0.77^{\mathrm{a}}$ & & $4.70 \pm 0.46^{\mathrm{a}}$ & $4.53 \pm 0.51^{\mathrm{a}}$ & $4.57 \pm 0.50^{\mathrm{a}}$ \\
\hline S100 & $4.83 \pm 0.38^{\mathrm{a}}$ & $4.37 \pm .61^{\mathrm{a}}$ & $4.80 \pm 0.41^{\mathrm{a}}$ & $4.17 \pm 0.65^{\mathrm{b}}$ & $4.27 \pm 0.74^{\mathrm{a}}$ & $4.13 \pm 0.73^{\mathrm{b}}$ & $4.67 \pm 0.48^{\mathrm{a}}$ & $4.33 \pm 0.71^{\mathrm{a}}$ & $4.67 \pm 0.48^{\mathrm{a}}$ \\
\hline
\end{tabular}

Different superscript lowercase letters show the significant differences for each sample group $(P<0.05)$. All experiments were performed in triplicate. All data are represented as means \pm standard deviation. $1=$ very bad, $2=$ bad, $3=$ moderately recognizable, $4=$ good, $5=$ very good. Number of panellists $(\mathrm{n})$ was 30 .

Table 4. Flow and melting behaviour of colored white compound chocolate.

\begin{tabular}{|c|c|c|c|c|c|c|c|}
\hline \multirow{2}{*}{ Sample } & \multicolumn{3}{|c|}{ Flow Behaviour } & \multicolumn{4}{|c|}{ Melting Behaviour } \\
\hline & $\sigma_{0}(\mathrm{~Pa})$ & $\eta_{p l}($ Pa.s $)$ & $R^{2}$ & $\mathrm{~T}_{\text {onset }}\left({ }^{\circ} \mathrm{C}\right)$ & $\mathrm{T}_{\text {peak }}\left({ }^{\circ} \mathrm{C}\right)$ & $\mathrm{T}_{\text {offset }}\left({ }^{\circ} \mathrm{C}\right)$ & $\Delta \mathrm{h}(\mathrm{J} / \mathrm{g})$ \\
\hline $\mathrm{C} 000$ & $1.68 \pm 0.25^{\mathrm{a}}$ & $2.09 \pm 0.01^{\mathrm{b}}$ & 0.995 & $21.3 \pm 0.38^{\mathrm{a}}$ & $32.1 \pm 0.26^{\mathrm{a}}$ & $40.8 \pm 0.83^{\mathrm{a}}$ & $35.3 \pm 1.55^{\mathrm{a}}$ \\
\hline $\mathrm{C} 050$ & $1.90 \pm 0.03^{\mathrm{a}}$ & $2.49 \pm 0.06^{\mathrm{a}}$ & 0.993 & $22.2 \pm 0.38^{\mathrm{a}}$ & $32.1 \pm 0.23^{\mathrm{a}}$ & $41.0 \pm 0.64^{\mathrm{a}}$ & $32.4 \pm 0.98^{\mathrm{a}}$ \\
\hline $\mathrm{C} 075$ & $1.89 \pm 0.12^{\mathrm{a}}$ & $2.48 \pm 0.12^{\mathrm{a}}$ & 0.993 & $21.3 \pm 0.85^{\mathrm{a}}$ & $32.5 \pm 0.92^{\mathrm{a}}$ & $40.5 \pm 1.67^{\mathrm{a}}$ & $34.4 \pm 0.44^{\mathrm{a}}$ \\
\hline $\mathrm{C} 100$ & $2.02 \pm 0.05^{\mathrm{a}}$ & $2.40 \pm 0.02^{\mathrm{a}}$ & 0.992 & $21.1 \pm 0.11^{\mathrm{a}}$ & $32.0 \pm 0.06^{\mathrm{a}}$ & $40.6 \pm 0.8^{\mathrm{a}}$ & $34.2 \pm 0.17^{\mathrm{a}}$ \\
\hline
\end{tabular}

Different superscript lowercase letters show the significant differences for each sample group $(P<0.05)$. All experiments were performed in triplicate. All data are represented as means \pm standard deviation.

Furthermore, the difference in moisture levels, albeit at a non-significant level, did not cause significant changes in compound chocolate melting behavior $(\mathrm{P}>0.05)$. Investigating the melting properties of chocolate samples is of great importance in order to learn about in-mouth melting behavior as well as some other physical properties of the fat phase such as hardness and crystallization properties (Braipson-Danthine \& Deroanne, 2004). $\mathrm{T}_{\text {onset, }}, \mathrm{T}_{\text {peak }}, \mathrm{T}_{\text {end }}$ and $\Delta \mathrm{h}$ values were determined as $21.1-22.2^{\circ} \mathrm{C}$, $32.0-32.5^{\circ} \mathrm{C}, 40.5-41.0^{\circ} \mathrm{C}$ and $32.4-35.3 \mathrm{j} / \mathrm{g}$, respectively. $\mathrm{T}_{\text {onset }}$ values of the samples obtained by crystallization of different levels of palm stearin/palm kernel olein mixtures under different conditions were determined in the range of $11.5-22.3^{\circ} \mathrm{C}$ (AbdRashid et al., 2012). Toker et al. (2016) determined the $\mathrm{T}_{\text {onset, }}$ $\mathrm{T}_{\text {peak }}$ and $\mathrm{T}_{\text {end }}$ values for compound chocolate as $21-25^{\circ} \mathrm{C}$, $30.9-33.8^{\circ} \mathrm{C}$ and $37.4-42.5^{\circ} \mathrm{C}$, respectively. Therefore, it was determined that the melting behavior characteristics obtained from this study were consistent with the previous studies and that the use of beetroot powder did not cause any negative change on the melting properties of the compound chocolate samples.

\subsection{Color properties and stability}

Color is one of the purchasing motivations for consumers which affects the perception and attitude towards food (Wu et al., 2013). As one of the aims of this study is a preliminary examination of the use of compound and spread chocolate as a means of distributing pigments that also have bioactive properties, the stability of changes in color properties and the stability of color properties were examined with the use of beetroot powder. In this study, by using CIE-Lab technique, the brightness $\left(L^{*}\right), a^{*}, b^{*}$, chroma $\left(\mathrm{C}^{\star}\right)$ and hue angle $\left(\mathrm{h}^{\circ}\right)$ properties and whiteness index (WI), which is an important color parameter in chocolate and derivative products, were determined (Table 5). With the use of beetroot powder in compound chocolate samples, significant decrease in $\mathrm{L}^{*}(54.9-74.4), \mathrm{b}^{*}(8.20-18.2), \mathrm{C}^{\star}(13.0-19.2), \mathrm{h}^{\circ}[(-72.0)-32.7]$ and WI (52.4-68.0) were observed, while the redness $\left(+\mathrm{a}^{*}\right)$ associated with the pigment source used showed a significant increase [(-5.90)-12.8] $(\mathrm{P}<0.05)$. Decreasing in brightness is a disadvantage for chocolate and chocolate products (Konar, 2013). However, the increase in the $a^{*}$ value consistent with the pigment level has been considered a positive indicator for the process stability of this pigment source and the possibility of its use in the compound chocolate matrix. With the use of beetroot powder, $\mathrm{L}^{*}(54.2-68.4), \mathrm{a}^{*}((-2.61)-10.78), \mathrm{b}^{*}(8.20-18.2), \mathrm{C}^{*}$ (13.3-17.5), $\mathrm{h}^{\circ}((-81.4)-80.2)$ and WI (51.9-63.9) properties of spread samples showed similar changes to the compound chocolate $(\mathrm{P}<0.05)$.

It is important that the visual properties gained by the use coloring agent, show stability during the shelf life of the samples. The shelf life of the white chocolate is considered to be around 12 months (Beckett, 2009). White chocolate and its products may show a higher tendency to loss of aroma and color during storage process as they contain a lower level of antioxidant components than other chocolate categories (Stauffer, 2007). All sample groups were stored under accelerated shelf life (ASL) conditions $\left(25^{\circ} \mathrm{C} / 70 \% \mathrm{RH}\right)$, prepared for confectionery including chocolate, and their color characteristics were determined for 7-days period of storage under ASL conditions were considered to simulate 1 month of normal storage conditions (Subramaniam, 2007). $\Delta \mathrm{E}$ values of all sample groups were determined for this aim. (Table 5 and 6 ). When $\Delta \mathrm{E}$ value is above 3.0 , it is 


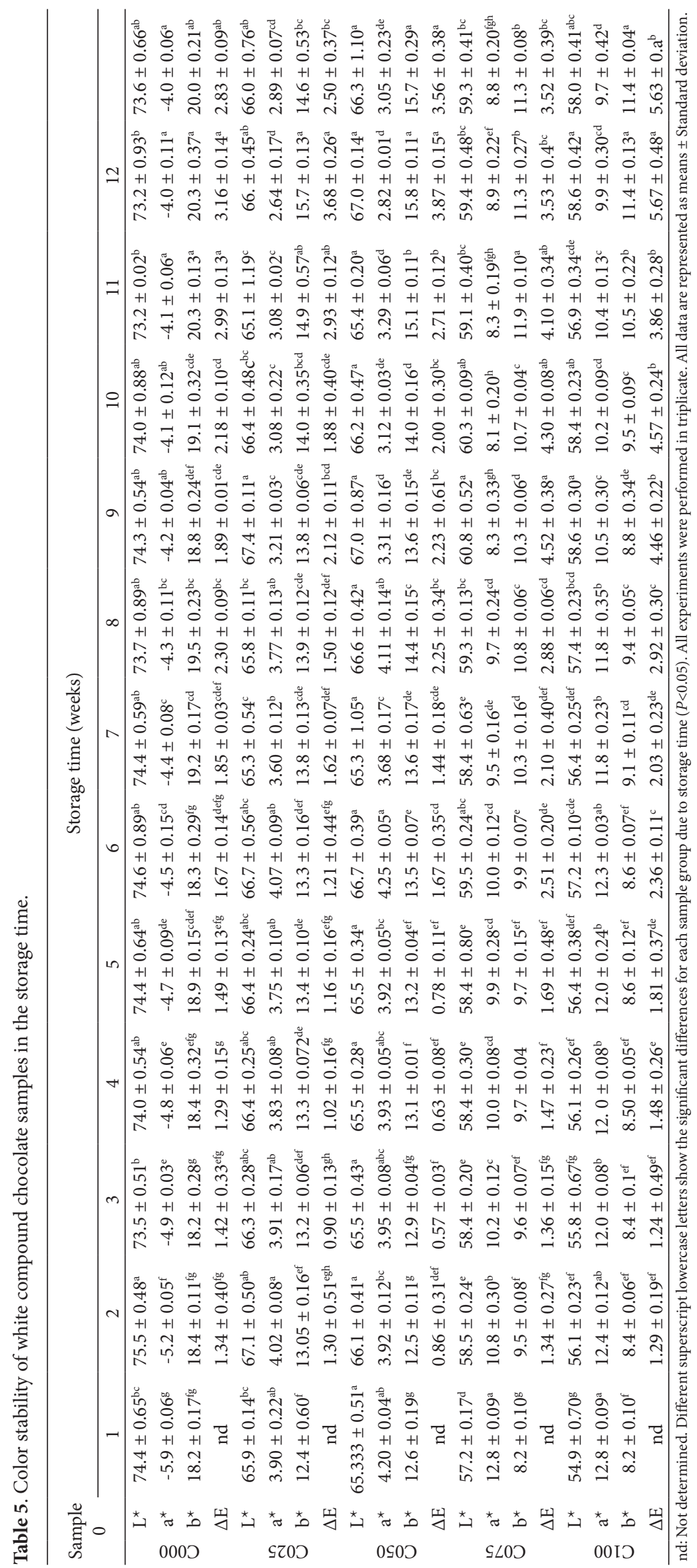




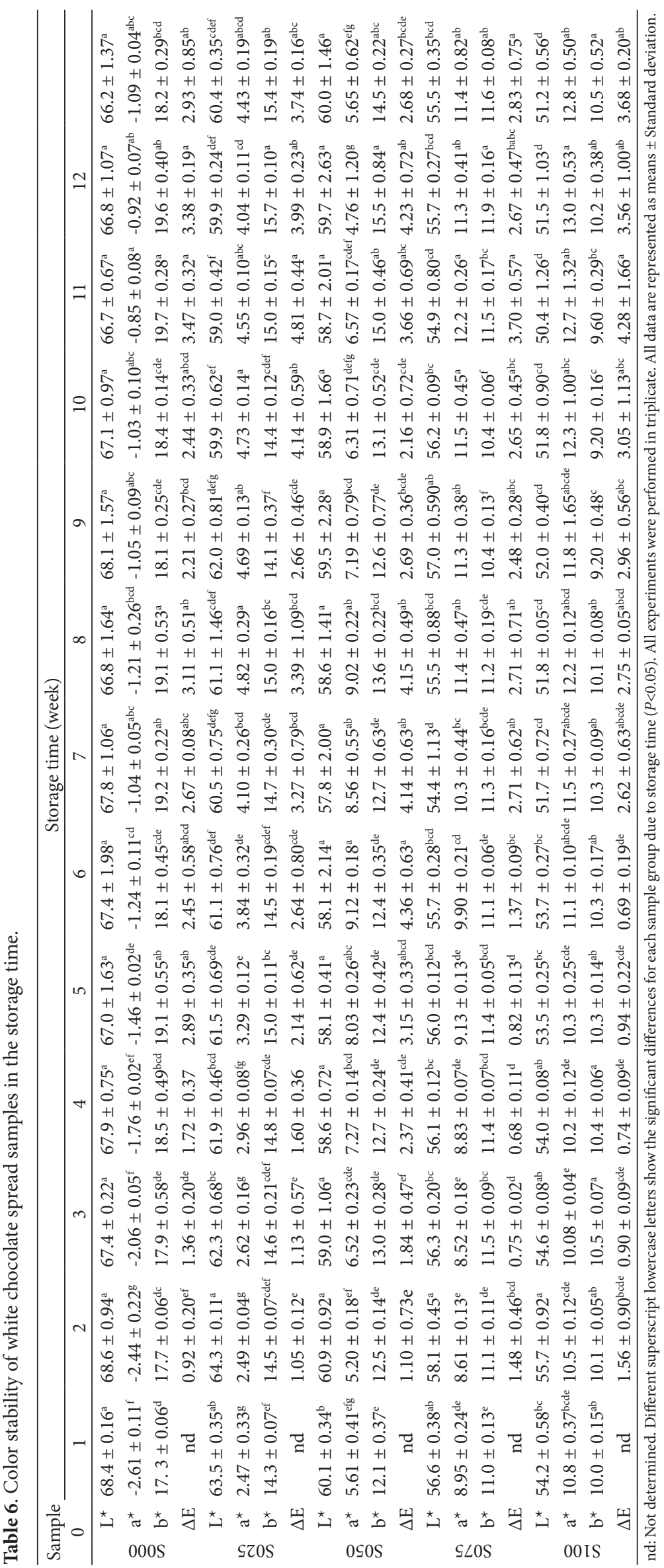


considered to be a visual color change (Periche et al., 2015). This value was generally lower than 3.16 in 12 weeks storage period under ASL conditions in compound chocolate samples. In the samples containing beetroot powder, lower color stability was observed in the samples with a usage rate of $>0.50 \mathrm{~g} / 100 \mathrm{~g}$ $(\mathrm{p}<0.05)$. In samples containing 0.25 and $0.50 \mathrm{~g} / 100 \mathrm{~g}$ beetroot powder, the color stability was found to be maintained under ASL conditions for 12 and 10 weeks, respectively. Some increases and decreases in the color values of both compound chocolate and spread samples were determined during the study (Table 5 and 6). Previous studies also observed some fluctuations in color properties during storage in white chocolate (Jardim et al., 2011). If these changes are considered negligible, the value of $\Delta \mathrm{E}$ for spread samples for samples containing 0.00 (control), $0.25,0.50,0.75$ and $1.00 \mathrm{~g} / 100 \mathrm{~g}$ beetroot powder is less than 3.0 under ASL conditions for 12, 8, 5, 12 and 9 weeks, respectively. Unlike compound chocolate, higher color stability was determined in spread samples where beetroot powder usage was higher $(0.75$ and $1.00 \mathrm{~g} / 100 \mathrm{~g})$. Therefore, it can be stated that the product compound is an important factor for color stability. In addition, it is worth to mention that among these sample groups, the samples with the highest moisture content and $0.50 \mathrm{~g} / 100 \mathrm{~g}$ beetroot powder has lower color stability. Most natural food colorants may show unstable behavior in process and storage conditions such as moisture, light, oxygen and $\mathrm{pH}$ (Wu et al., 2013). It is possible to reach higher color stability both for compound chocolate and spread, especially with the optimization of moisture level and the use of components that improve oxidative stability.

\section{Conclusion}

Various bioactive compounds have both technological and functional effects on foods. Betalains and beetroot powder, which is the source of this bioactive component, are significant food components with both coloring and bioactivity effects. Before using this and other colorant-containing components in developing functional product, it is important to investigate their effects on the quality properties of foods and also ensure the stability of the visual properties they provide throughout shelf life.

In this study, it was determined that the use of beetroot powder did not cause significant deviations on physico-chemical, texture, flow, melting and sensory properties of the spread and compound chocolate. The sensory evaluation shows that the products that were obtained in this study are determined to be accepted by the consumer. It can be stated that the stability of the visual properties in the spread and compound chocolate samples should be increased. Considering results of sensory analysis and color stability under ASL conditions, $2.50 \mathrm{~g} \mathrm{~kg}^{-1}$ and $7.50 \mathrm{~g} \mathrm{~kg}^{-1}$ beetroot powder may be used to develop compound and spread chocolate, respectively, with improved and stable visual properties. By further studies bioaccesibility and functional properties of spread and compound chocolates including plantorigin bioactive compounds should be investigated.

\section{Acknowledgements}

The authors would like to thank the Tayas Food Company (Kocaeli, Turkey) for the pilot-scale of white compound chocolate and white chocolate spread.

\section{References}

Abd-Rashid, N., Chiew, L. C., Chong Seng, C., \& Omar, Z. (2012). Crystallisation kinetics of palm stearin, palm kernel olein and their blends. Lebensmittel-Wissenschaft + Technologie, 46(2), 571-573. http://dx.doi.org/10.1016/j.lwt.2011.11.001.

Afoakwa, E. O. (2010). Chocolate science and technology. United Kingdom: John Wiley \& Sons. http://dx.doi.org/10.1002/9781444319880.

Afoakwa, E. O., Paterson, A., Fowler, M., \& Vieira, J. (2008). Modelling tempering behavior of dark chocolates from varying particle size distribution and fat content using response surface methodology. Innovative Food Science \& Emerging Technologies, 9(4), 527-533. http://dx.doi.org/10.1016/j.ifset.2008.02.002.

Beckett, S. T. (2009). Industrial chocolate manufacture and use (4th ed.). United Kingdom: Wiley-Blacwell Publication.

Braipson-Danthine, S., \& Deroanne, C. (2004). Influence of SFC, microstructure and polymorphism on texture (hardness) of binary blends of fats involved in the preparation of industrial shortenings. Food Research International, 37(10), 941-948. http://dx.doi.org/10.1016/j. foodres.2004.06.003.

Clifford, T., Howatson, G., West, D. J., \& Stevenson, E. J. (2015). The potential benefits of red beetroot supplementation in health and disease. Nutrients, 7(4), 2801-2822. http://dx.doi.org/10.3390/ nu7042801. PMid:25875121.

Delgado-Vargas, F., Jimenez, A. R., \& Paredes-Lopez, O. (2000). Natural pigments: carotenoids, anthocyanins, and betalains e characteristics, biosynthesis processing and stability. Critical Reviews in Food Science and Nutrition, 40(3), 173-289. http://dx.doi. org/10.1080/10408690091189257. PMid:10850526.

Fayaz, G., Goli, S. A. H., Kadivar, M., Valoppi, F., Barba, L., Calligaris, S., \& Nicoli, M. C. (2017). Potential application of pomegranate seed oil oleogels based on monoglycerides, beeswax and propolis wax as partial substitutes of palm oil in functional chocolate spread. Lebensmittel-Wissenschaft + Technologie, 86, 523-529. http://dx.doi. org/10.1016/j.lwt.2017.08.036.

Gengatharan, A., Dykes, G. A., \& Choo, W. S. (2015). Betalains: natural plant pigments with potential application in functional foods. Lebensmittel-Wissenschaft + Technologie, 64(2), 645-649. http:// dx.doi.org/10.1016/j.lwt.2015.06.052.

Georgiev, V. G., Weber, J., Kneschke, E.-M., Denev, P. N., Bley, T., \& Pavlov, A. I. (2010). Antioxidant activity and phenolic content of betalain extracts from intact plants and hairy root cultures of the red beetroot Beta vulgaris cv. Detroit dark red. Plant Foods for Human Nutrition, 65(2), 105-111. http://dx.doi.org/10.1007/s11130-0100156-6. PMid:20195764.

Glicerina, V., \& Romani, S. (2016). Advances in yield stress measurements for chocolate. In J. Ahmed, P. Ptaszek \& J. Basu (Eds.), Advances in food rheology and its applications (pp. 459-481). Cambridge: Woodhead Publishing.

Glicerina, V., Balestra, F., Dalla Rosa, M., \& Romani, S. (2013). Rheological, textural and colorimetric modifications of dark chocolate during process. Journal of Food Engineering, 119(1), 173-179. http://dx.doi. org/10.1016/j.jfoodeng.2013.05.012.

Gliszczyńska-Swigło, A., Szymusiak, H., \& Malinowska, P. (2006). Betanin, the main pigment of red beet: molecular origin of its exceptionally high free radical-scavenging activity. Food Additives and Contaminants, 23(11), 1079-1087. http://dx.doi.org/10.1080/02652030600986032. PMid:17071510.

Jardim, D. C., Orse, A. G., Efraim, P., \& Moura, S. C. (2011). Kinetic of white chocolate color loss. Procedia Food Science, 1, 1026-1030. http://dx.doi.org/10.1016/j.profoo.2011.09.153. 
Konar, N. (2013). Influence of conching temperature and some bulk sweeteners on physical and rheological properties of prebiotic milk chocolate containing inulin. European Food Research and Technology, 236(1), 135-143. http://dx.doi.org/10.1007/s00217-012-1873-x.

Konar, N., \& Bingol, I. (2019). Effect of ball-mill process on some quality parameters of chocolate and compound chocolate: a modeling approach. Journal of Food Process Engineering, 42(6), e13154. http:// dx.doi.org/10.1111/jfpe.13154.

Lončarević, I., Pajin, B., Fistes, A., Tumbas Saponjac, V., Petrovic, J., Jovanovic, P., Vulic, J., \& Zaric, D. (2018). Enrichment of white chocolate with blackberry juice encapsulate: Impact on physical properties, sensory characteristics and polyphenol content. Lebensmittel-Wissenschaft + Technologie, 92, 458-464. http://dx.doi. org/10.1016/j.lwt.2018.03.002.

Lonchampt, P., \& Hartel, R. W. (2006). Surface bloom on improperly tempered chocolate. European Journal of Lipid Science and Technology, 108(2), 159-168. http://dx.doi.org/10.1002/ejlt.200500260.

Manzocco, L., Calligaris, S., Camerin, M., Pizzale, L., \& Nicoli, M. C. (2014). Prediction of firmness and physical stability of low-fat chocolate spreads. Journal of Food Engineering, 126, 120-125. http:// dx.doi.org/10.1016/j.jfoodeng.2013.10.042.

Martins, N., Roriz, C. L., Morales, P., Barros, L., \& Ferreira, I. C. (2016). Food colorants: challenges, opportunities and current desires of agro-industries to ensure consumer expectations and regulatory practices. Trends in Food Science \& Technology, 52, 1-15. http:// dx.doi.org/10.1016/j.tifs.2016.03.009.

McGill, J., \& Hartel, R. W. (2018). Investigation into the microstructure, texture and rheological properties of chocolate ganache. Journal of Food Science, 83(3), 689-699. http://dx.doi.org/10.1111/17503841.14053. PMid:29355953.

Morato, P. N., Rodrigues, J. B., Moura, C. S., Silva, F. G. D., Esmerino, E. A., Cruz, A. G., Bolini, H. M. A., Amaya-Farfan, J., \& Lollo, P. C. B. (2015). Omega-3 enriched chocolate milk: a functional drink to improve health during exhaustive exercise. Journal of Functional Foods, 14, 676-683. http://dx.doi.org/10.1016/j.jff.2015.02.034.

Nascimento, M. S., Brum, D. M., Pena, P. O., Berto, M. I., \& Efraim, P. (2012). Inactivation of Salmonella during cocoa roasting and chocolate conching. International Journal of Food Microbiology, 159(3), 225-229. http://dx.doi.org/10.1016/j.ijfoodmicro.2012.08.017. PMid:23107501.

Otálora, M. C., Jesús Barbosa, H., Perilla, J. E., Osorio, C., \& Nazareno, M. A. (2019). Encapsulated betalains (Oputia ficus-indica) as natural colorants. Case study: gummy candies. Lebensmittel-Wissenschaft + Technologie, 103, 222-227. http://dx.doi.org/10.1016/j.lwt.2018.12.074.

Periche, A., Heredia, A., Escriche, I., Andrés, A., \& Castello, M. L. (2015). Potential use of isomaltulose to produce healthier marshmallows. Lebensmittel-Wissenschaft + Technologie, 62(1), 605-612. http:// dx.doi.org/10.1016/j.lwt.2014.12.024.

Rivoira, L., Studzińska, S., Szultka-Młyńska, M., Bruzzoniti, M. C., \& Buszewski, B. (2017). New approaches for extraction and determination of betaine from Beta vulgaris samples by hydrophilic interaction liquid chromatography-tandem mass spectrometry. Analytical and Bioanalytical Chemistry, 409(21), 5133-5141. http://dx.doi. org/10.1007/s00216-017-0461-0. PMid:28664334.

Saint-Eve, A., Deleris, I., Panouille, M., Dakowski, F., Cordelle, S., Schlich, P., \& Souchon, I. (2011). How texture influences aroma and taste perception over time in candies. Chemosensory Perception, 4(1-2), 32-41. http://dx.doi.org/10.1007/s12078-011-9086-4.

Schantz, B., \& Rohm, H. (2005). Influence of lecithin-PGPR blends on the rheological properties of chocolate. Lebensmittel-Wissenschaft + Technologie, 38(1), 41-45. http://dx.doi.org/10.1016/j.lwt.2004.03.014.
Schumacher, A. B., Brandelli, A., Schumacher, E. W., Macedo, F. C., Pieta, L., Klug, T. V., \& de Jong, E. V. (2009). Development and evaluation of a laboratory scale conch for chocolate production. International Journal of Food Science \& Technology, 44(3), 616-622. http://dx.doi.org/10.1111/j.1365-2621.2008.01877.x.

Servais, C., Ranc, H., \& Roberts, I. D. (2003). Determination of chocolate viscosity. Journal of Texture Studies, 34(5-6), 467-497. http://dx.doi. org/10.1111/j.1745-4603.2003.tb01077.x.

Sethi, N., \& Balasubramanyam, B. V. (2018). Optimization of butter fruit incorporated fat spread using instrumental textural analysis: a response surface methodology. Journal of Food Measurement and Characterization, 12(2), 859-866. http://dx.doi.org/10.1007/s11694-017-9700-5.

Shourideh, M., Taslimi, A., Azizi, M. H., \& Mohammadifar, M. A. (2012). Effects of D-tagaose and inulin of some physicochemical, rheological and sensory properties of dark chocolate. International Journal of Bioscience, Biochemistry, Bioinformatics, 2(5), 314-319. http://dx.doi.org/10.7763/IJBBB.2012.V2.124.

Stauffer, M. (2007). Conquering shelf-life issues of chocolate. Manufacturing Confectioner, 47-51.

Subramaniam, P. J. (2007). Determining shelf-life of confectionery products. Manufacturing Confectioner, 87(6), 85-91.

Tan, J., \& Balasubramanian, B. M. (2017). Particle size measurements and scanning electron microscopy (SEM) of cocoa particles refined/conched by conical and cylindirical roller stone melangers. Journal of Food Engineering, 212, 146-153. http://dx.doi.org/10.1016/j.jfoodeng.2017.05.033.

Toker, O. S., Sagdic, O., Sener, D., Konar, N., Zorlucan, T., \& Daglioglu, O. (2016). The influence of particle size on some physicochemical, rheological and melting properties and volatile compound profile of compound chocolate and cocolin samples. European Food Research and Technology, 242(8), 1253-1266. http://dx.doi.org/10.1007/ s00217-015-2629-1.

Toker, O. S., Zorlucan, F. T., Konar, N., Dağlıŏlu, O., Sagdic, O., \& Şener, D. (2017). Investigating the effect of ball mill refiner conditions on some physical quality parameters of compound chocolate: response surface methodology approach. International Journal of Food Science \& Technology, 52(3), 788-799. http://dx.doi.org/10.1111/ijfs.13336.

Vavreck, A. N. (2004). Flow of molten milk chocolate from an efflux viscometer under vibration at various frequencies and displacements. International Journal of Food Science \& Technology, 39(4), 465-468. http://dx.doi.org/10.1111/j.1365-2621.2004.00805.x.

Wolf, B. (2017). Chocolate flow properties. In S. T. Beckett, M. S. Fowler \& G. R. Ziegler (Eds.), In Beckett's industrial chocolate manufacture and use (5th ed., pp. 274-297). West Sussex: Wiley Blackwell. http:// dx.doi.org/10.1002/9781118923597.ch11.

Wu, H., Guo, J.-B., Du, L.-M., Tian, H., Hao, C.-X., Wang, Z.-F., \& Wang, J.-Y. (2013). A rapid shaking-based ionic liquid dispersive liquid phase microextraction for the simultaneous determination of six synthetic food colourants in soft drinks, sugar- and gelatinbased confectionery by high-performance liquid chromatograph. Food Chemistry, 141(1), 182-186. http://dx.doi.org/10.1016/j. foodchem.2013.03.015. PMid:23768345.

Ziegler, G. R., Mongia, G., \& Hollender, R. (2001). Role of particle size distribution of suspended solids in defining the sensory properties of milk chocolate. International Journal of Food Properties, 4(2), 353-370. http://dx.doi.org/10.1081/JFP-100105199. 